\title{
CITAS DE AUTORIDADES Y ARGUMENTACIÓN RETÓRICA EN LAS POLÉMICAS LITERARIAS SOBRE EL ESTILO CULTO
}

\author{
Antonio AZAUSTRE GALIANA \\ Universidad de Santiago de Compostela*
}

Resumen: Este artículo ofrece varios ejemplos del uso de las citas de autoridades en las polémicas literarias sobre el estilo culto en la poesía del Siglo de Oro. Estas autoridades fueron a menudo manejadas por sus detractores y defensores como un recurso de argumentación que utilizaba los mismos pasajes o los fragmentaba en beneficio de sus puntos de vista. Se comentan lugares de San Jerónimo, Aristóteles, Petronio u Horacio, entre otros.

Résumé: Cet article donne plusieurs exemples de l'usage de citations d'autorités dans les polémiques littéraires sur la langue soutenue dans la poésie du Siècle d'Or. Ces autorités ont été souvent utilisées par leurs détracteurs ou défenseurs détournant les mêmes citations pour bénéficier leurs propres points de vue. On analyse des citations de saint Jérôme, Aristote, Pétrone et Horace.

\footnotetext{
*Algunas de estas consideraciones aparecen en el Homenaje al profesor Cristóbal Cuevas García.
} 
Palabras clave: Retórica. Argumentación. Citas de autoridades. Poesía del Siglo de Oro.

Mots clé: Rhétorique, Argumentation, Citations des autorités, Poésie du Siècle d'Or.

Las discusiones sobre el estilo culto en poesía tuvieron su punto álgido en nuestras letras con la fama adquirida por los poemas mayores de Góngora y la proliferación de su estilo, aunque se encuentran ecos anteriores a raíz de las Anotaciones de Fernando de Herrera a la poesía de Garcilaso. Es, en último término, una discusión heredera del antiguo enfrentamiento entre asianistas y aticistas, mencionado a menudo como antecedente suyo.

Esta polémica literaria puede enfocarse también como una pugna argumentativa en sentido retórico. Diversos preceptistas y escritores intervinieron en defensa o censura del estilo que proliferó con la fama de Góngora. Para sostener sus puntos de vista se apoyaron en las afirmaciones de autores consagrados, en su mayor parte pertenecientes al campo de la poética y la retórica ${ }^{1}$, puesto que la discusión giraba a menudo sobre estas cuestiones. En este ámbito unos y otros manejaban las mismas autoridades y las orientaban argumentativamente hacia la defensa de sus puntos de vista ${ }^{2}$.

\footnotetext{
${ }^{1}$ Véanse, entre otros, Romanos (1983), Jammes (1994: 84-101 y 607-719), Roses Lozano (1994: 9-65).

${ }^{2}$ Es aspecto estudiado por la crítica; véanse Weinberg (1961: 712), que constata el uso de Aristóteles como autoridad para defender y criticar nuevos géneros literarios; también Smith (1987: 5051) quien lo atestigua en el caso de Quevedo y sus preliminares a su edición de la poesía de fray Luis de León.
} 


\section{LAS CITAS DE AUTORIDADES EN EL SISTEMA DE LA RETÓRICA}

Este tipo de citas constituye un procedimiento de argumentación que la retórica estudiaba en el ámbito de varios recursos ${ }^{3}$. Uno de ellos es la prueba externa conocida como auctoritas, que define así Quintiliano ${ }^{4}$ :

Adhibetur extrinsecus in causam et auctoritas. Haec secuti Graecos, a quibus krVisei dicuntur, iudicia aut iudicationes vocant, non de quibus ex causa dicta sententia est (nam ea quidem in exemplorum locum cedunt), sed si quid ita visum gentibus, populis, sapientibus viris, claris civibus, illustribus poetis referri potest (Quintiliano, Institutio Oratoria, 5, 11, 36)

('A la causa se aplicará también como prueba externa la auctoritas. A ella se la llama, según los griegos, que la denominan krísis, sentencias o juicios. Pero no es la sentencia u opinión salida de un pleito -pues éstas pasan a ocupar un lugar en los ejemplos-, sino de lo que puede aducirse del pensamiento de naciones, pueblos, hombres sabios, ciudadanos destacados $e$ ilustres poetas')

En virtud de la conexión existente entre las diversas esferas de la retórica, la auctoritas se vincula a otros recursos. Como ya apuntaba la anterior definición de Quintiliano, guarda relación con la sententia, un pensamiento o idea de carácter general o infinito ${ }^{5}$ :

\footnotetext{
${ }^{3}$ La caracterización que aquí se hará de las citas de autoridades las entiende en su dimensión retórica, como un procedimiento de argumentación. Ello no agota las posibilidades de acercamiento al complejo fenómeno de la cita; por ejemplo, la Teoría de la Literatura y la Literatura Comparada estudian la cita como una de las manifestaciones de la intertextualidad, concepto amplio que comprende los distintos tipos de relación de un texto con otros; véanse, entre otras aportaciones, Plett (1993: 70-80), Martínez Fernández (2001: 82-91). Tampoco me ocuparé aquí de estudiar aspectos tan importantes como los procedimientos de inserción de citas en el texto, cuestión ya abordada en estudios clásicos como los de Schlicher (1905), Hendrick (1906) o Andrieu (1949).

${ }^{4}$ En síntesis, las pruebas inartísticas o internas son aquellas que no precisan del arte retórica para su aplicación, pues vienen dadas por la causa; las artísticas o externas son aquellas que se construyen con la ayuda de diversos procedimientos de la retórica. Más detalles sobre esta distinción pueden verse en Quintiliano, Institutio Oratoria, 5, 1.

${ }^{5}$ Así la define una de las más destacadas retóricas hispanas del XVI: «Es la sentencia una oracion tomada de la vida, la cual manifiesta brevemente lo que hay ó lo que conviene haber en la vida» (Fray Luis de Granada, Retórica eclesiástica, 2, 13, 1); continúa luego detallando sus tipos, con alguna referencia a lo expuesto por Quintiliano, y prestando especial atención a la predicación. Es evidente que no se trata aquí de la otra acepción retórica de sentencia, que la entiende como resolución de un pleito.
} 
Adagio o sentencia es una aseveración, pero ciertamente no de cosas particulares, por ejemplo, cómo es Ifícrates, sino sobre lo universal, mas tampoco de todo lo universal, por ejemplo, que lo recto es contrario de lo curvo, sino de aquello sobre que versan las acciones y puede elegirse o evitarse al obrar, de manera que dado que es entimema el silogismo sobre tales cosas, vienen a ser sentencias las conclusiones y premisas de los entimemas, quitado el silogismo (Aristóteles, Retórica, 2, 21, 1394 a ) ${ }^{6}$.

Sententia est oratio sumpta de uita quae aut quid sit aut quid esse oporteat in uita breuiter ostendit» (Rhetorica ad Herennium, 4, 17, 24)

('Sentencia es un dicho tomado de la vida, que muestra brevemente qué sucede o qué debe suceder en ella')

Sententiam ueteres quod animo sensissent uocauerunt. Id cum est apud oratores frequentissimum, tum etiam in usu cotidiano quasdam reliquias habet; nam et iuraturi «ex animi nostri sententia» et gratulantes «ex sententia» dicimus. Non raro tamen et sic locuti sunt, ut «sensa» sua dicerent. Nam sensus corporis uidebantur. Sed consuetudo iam tenuit ut mente concepta sensus uocaremus, lumina autem praecipueque in clausulis posita sententias (Quintiliano, Institutio Oratoria, 8, 5, 1-2) ${ }^{7}$

('Los antiguos llamaron sentencia a aquello que sentían en el alma. Este es el sentido más frecuente del término entre los oradores, e incluso deja algunas huellas en el habla cotidiana pues, en el momento de prestar juramento decimos "por lo que sentimos", y cuando agradecemos algo decimos "desde nuestro corazón". No resulta extraño que algunos usasen la palabra sensa con el mismo valor, puesto que sensus les parecía referirse al cuerpo. Pero la costumbre que llamemos sensus a los conceptos del alma, y sentencias a los dichos brillantes, y sobre todo colocados al final de las cláusulas').

${ }^{6}$ La definición muestra que Aristóteles entendía las sentencias o gnômai como un recurso argumentativo de la inventio; más concretamente, las identificaba con la premisa de validez general que sostenía la prueba lógica del entimema. Véase también el siguiente pasaje: "Queda ahora tratar de los argumentos retóricos comunes a todos los géneros, una vez que hemos tratado de los especiales. Los argumentos retóricos comunes son de dos géneros: el ejemplo y el entimema, porque el adagio es una parte del entimema" (Aristóteles, Retórica, 2, 20, 1393a 20). La relación entre la auctoritas de Quintiliano y las gnômai de Aristóteles es incluso de equivalencia para Compagnon (1979: 141): "L'auctoritas, elle, est une opinion publique ou la parole d'un sage, ce qui, comme on l'a vu chez Aristote, revient au même: les auctoritates que cite Quintilien équivalent aux gnômai ou aux endoxa d'Aristote, et ce que ne sont des exemples qu'en un sens lâche".

${ }^{7}$ A continuación Quintiliano (Institutio Oratoria, 8, 5, 3-4) se detiene en el tipo más antiguo de sentencias, las gnômai de los griegos, y muestra con claridad que su idea de sentencia es más amplia que el de Aristóteles, pues afirma que no todas ellas pueden explicarse como parte del entimena: "Hanc quidam partem enthymematis, quidam initium aut clausulam epichirematis esse dixerunt, et est aliquando, non tamen semper" ('Algunos dijeron que las sentencias eran parte del entimema, o bien el comienzo o el cierre de un epiquerema; esto es cierto en ocasiones, pero no siempre'). 
El vínculo entre auctoritas y sententia se observa con claridad cuando se recomienda que estas últimas hayan sido pronunciadas por personas de experiencia y criterio contrastado ${ }^{8}$ :

Corresponde usar sentencias, por la edad, a los viejos, y por los asuntos, en los que el que habla es experimentado, de manera que el usar sentencias cuando no se es de dicha edad, es impropio, lo mismo que el contar historias; y en lo que no se tiene experiencia, es necio y de falta de educación (Aristóteles, Retórica, 2, 21, 1395a).

Magis enim decet eo sin quibus est auctoritas, ut rei pondus etiam persona confirmet. Quis enim ferat puerum aut adulescentulum aut etiam ignobilem si iudicet in dicendo et quodam modo praecipiat? (Quintiliano, Institutio Oratoria, 8, 5, 8)

('Es mejor siempre que las pronuncie persona de alguna autoridad o que otorgue peso al asunto. Porque, ¿quién podrá tolerar que un niño, un joven o alguien vulgar se ponga a hacer de juez o experto?')

Otro recurso retórico que guarda notables semejanzas con la auctoritas y la sententia es la chría: un pensamiento o dicho de carácter general atribuidos a un personaje histórico de fama, y enmarcados en una breve anécdota a él referida. La chría era muy trabajada en los ejercicios de retórica ${ }^{9}$; Hermógenes, por ejemplo, se ocupa de la chría inmediatamente antes de estudiar la sentencia y manifiesta con claridad la semejanza existente entre ambas:

Una sentencia es una máxima expresada en una enunciación general, que desaconseja algo o exhorta hacia algo o que pone de manifiesto el carácter de cada cosa [...] O bien no hace nada de eso, sino que emite una declaración acerca de la naturaleza del hecho [...]. La elaboración, semejante a la de la chría, discurrirá por los siguientes apartados: encomio breve de quien la ha dicho, como en la chría, sencillez, causa, argumento contrario, razonamiento, símil, ejemplo y emisión de un juicio (Hermógenes, Ejercicios de retórica, pp. 181-82).

${ }^{8}$ Este vínculo lo señala también Lausberg (1966: § 872): «En cuanto prueba la sententia entraña una auctoritas». De hecho, la sententia podría considerarse el cauce habitual de expresión para la auctoritas; Quintiliano se ocupa por extenso de la sententia en Institutio Oratoria 8, 5, esto es, dentro del libro destinado a la elocución. Así lo cree Compagnon (1979: 143-44), que estudia sus características en Aristóteles y Quintiliano.

${ }^{9}$ Sobre la chría, véanse Teón (p. 105), Hermógenes (p. 179) y Aftonio (p. 219) 
Auctoritas, sententia y chría son, pues, un conjunto de procedimientos retóricos que expresan un pensamiento de validez general, a menudo reforzado por el peso de quien las había pronunciado en su origen ${ }^{10}$. Su valor como procedimiento de argumentación se encuentra más cercano a las pruebas externas o artísticas, es decir, aquellas traídas de fuera de la causa o asunto que se trata y cuyo vínculo con ella debe ser establecido por el orador, quien debe aportar su dominio de la ars para construirlas $^{11}$.

Sin embargo, y como sucede en la mayoría de las dimensiones retóricas, esta clasificación dista de ser rígida. Así, en su estudio de la argumentación, Quintiliano considera la auctoritas como una de las denominadas pruebas retóricas externas; pero al reconocer que en ocasiones muestra semejanzas con la prueba inartística del testimonio $^{12}$, Quintiliano está mostrando la tenue frontera que separa a la auctoritas de las pruebas inartísticas, esto es, las que no necesitan la manipulación del orador pues

${ }^{10}$ Esa fuerza se nota especialmente en algunas épocas y contextos, como la Edad Media y la literatura religiosa, donde el principio de autoridad y la cita de autoridades adquieren una gran importancia; véase al respecto Compagnon (1979: 155 y ss.). El principio de autoridad es, además, un valor argumentativo general que afecta a otras pruebas y recursos concretos de argumentación. Cicerón, por ejemplo, reconoce su importancia al hablar de la prueba inartística del testimonio, tal y como ya señaló Smith (1987: 51): "Haec ergo argumentatio quae dicitur artis expers, in testimonio posita est. Testimonium autem nunc dicimus omne quod ab aliqua re externa sumitur ad faciendam fidem. Persona autem non qualiscunque est testimoni pondus habet; ad fidem enim faciendam auctoritas quaeritur; sed auctoritatem aut natura aut tempus adfert" (Cicerón, Tópica, 19, 73).

${ }^{11}$ Para la argumentación y los tipos de pruebas, véanse Aristóteles, Retórica, libros 1 y 2; Rhetorica ad Herennium, libro 2; Cicerón, Tópica, 1, 8-4, 24; De inventione, libro 1; Quintiliano, Institutio oratoria, 5,1 , y ss.

12 "Nonnumquam contingit iudicis quoque aut aduersarii aut eius, qui ex diuerso agit, dictum aliquod aut factum adsumere ad eorum, quae intendimus, fidem. Propter quod fuerunt qui exempla et has auctoritates inartificialium probationum esse arbitrarentur, quod ea non inueniret orator, sed acciperet. Plurimum autem refert; nam testis et quaestio et his similia de ipsa re, quae in iudicio est, pronuntiant; extra petita, nisi ad aliquam praesentis disceptationis utilitatem ingenio adplicantur, nihil per se ualent (Quintiliano, Institutio Oratoria, 5, 12, 43-44). Esa conexión entre cita de autoridad y testimonio se apreciaba ya en la definición que Aristóteles daba de esta última prueba: "Los testigos son de dos clases, unos antiguos, otros recientes, y de estos últimos, los unos participan del riesgo del acusado, los otros están fuera. Llamo antiguos a los poetas y a todos los famosos cuyos juicios son conocidos; así los atenienses se sirvieron de Homero como testigo acerca de Salamina, y los de Ténedos poco ha de Periandro deCorinto contra los de Sigeo, y Cleofonte contra Critias se sirvió de las elegías de Solón [...] Acerca de las futuras, también lo son [testigos] los adivinos [...] Y también los proverbios[...] Son testigos recientes cuantas personas conocidas han opinado algo, pues sus juicios son útiles para los que disputan sobre las mismas cosas; así Eubulo en los tribunales se sirvió contra Cares de lo que Platón había dicho contra Arquibio [...]. Los que están lejos en cambio son los más fidedignos testigos sobre esto, y los más dignos de fe son los antiguos, porque no pueden ser corrompidos (Aristóteles, Retórica, 1, 15, 1375b$76 a)$. 
se refieren ya al asunto que se aborda. Esta conexión se observa también en casos como el que ahora nos ocupa; como ya se ha indicado, las citas de autoridades empleadas en las polémicas áureas sobre el estilo culto pertenecen a menudo a un autor y tema muy relacionados o coincidentes con el que se está abordando, pues se trata de opiniones de escritores y preceptistas que también versaban sobre el estilo y su ornamento; en consecuencia, el acercamiento analógico que debe lograr quien recurre a ellas no se precisa en tanta medida ${ }^{13}$. Como veremos posteriormente, ello no significa que ese juicio no deba ser adaptado a las circunstancias concretas de la polémica y a la opinión que en ella defiende quien acude a las autoridades como auxilio. Para ello, el orador o escritor que citan una autoridad recurren a diversos procedimientos, algunos de los cuales se ejemplificarán en estas páginas. Uno de los más frecuentes consiste en extraer y citar sólo aquella parte del texto que más se adecua a sus intereses omitiendo, si es el caso, los fragmentos más alejados de su opinión. Otra forma consiste en torcer el sentido de la fuente matizando el significado de alguna de sus frases o palabras para acercarlo a la postura propia: las citas de autoridades traducidas de otra lengua sufren a menudo este tipo de adaptación.

Una vez expuestos algunos rasgos generales de la auctoritas desde un punto de vista retórico, se repasarán algunos de sus usos en las discusiones sobre el estilo de la poesía en el Siglo de Oro.

\section{SAN JERÓNIMO Y EL VULGO IGNORANTE}

La dificultad de la poesía culta se calificaba a menudo con el término oscuridad, pues la obscuritas era el vicio opuesto a la virtud retórica de la claridad o perspicuitas. Esa oscuridad la hacía ininteligible para la mayoría de los lectores. Ante estas

${ }^{13}$ En estos casos el funcionamiento de la auctoritas se asemeja al del testimonio, como afirmaba Quintiliano, o también a la prueba interna del praeiudicium: una sentencia judicial o ley promulgadas con anterioridad sobre el mismo asunto que se está tratando, o sobre uno muy similar; véase Quintiliano, Institutio Oratoria, 5, 2, para sus diferentes tipos y rasgos; sobre esta conexión con ambos tipos de pruebas, véase también Azaustre (1996: 289-92). La situación de la cita de autoridades en un punto intermedio entre las pruebas inartísticas e inartísticas también se reconoce desde los acercamientos de la teoría literaria; Compagnon (1979: 60-65) la considera fronteriza entre los dos tipos de pruebas, y equiparable, por tanto, al signum. 
acusaciones, el propio Góngora se defendió abanderando con orgullo una poesía difícil destinada al disfrute de una minoría docta $^{14}$. Para rebatir este punto de vista, los detractores del poeta cordobés recurrieron más de una vez a un pasaje de san Jerónimo: su epístola Ad Nepotianum $(52,8)$, donde san Jerónimo instruía al presbítero Nepociano sobre el modo de hablar en la predicación, apoyándose en consejos de su maestro san gregorio Nacianceno ${ }^{15}$. Normalmente se citaba el pasaje de la epístola donde se afirmaba que el vulgo ignorante gustaba más de aquello que no entendía; así se pretendía contrarrestar la afirmación de que la dificultad de comprensión era patrimonio de los doctos:

Dicente te in ecclesia non clamor populi, sed gemitus suscitetur; lacrimae auditorum laudes tuae sint; sermo presbyteri scipturarum lectione conditus sit. Nolo te declamatorem esse et rabulam arrulumque, sed mysterii peritum et sacramentorum Dei tui eruditissimum. Verba uoluere et celeritate dicendi apud inperitum uulgus admirationem sui facere indoctorum hominum est. Adtrita frons interpretatur saepe quod nescit, et cum aliis suaserit sibi quoque usurpat scientiam. Praeceptor quondam meus Gregorius Nazanzenus rogatus a me ut exponeret quid sibi uellet in Luca sabbatum $\Omega m \diamond \diamond m \square \square * \square \square \bullet \bullet \square$, id est «secundoprimum», eleganter lusit: «docebo te» inquiens «super hac re in ecclesia, in qua omni nihi populo adclamante cogeris inuitus scire quod nescis, aut certe, si solus tacueris, solus ab omnibus stultitiae condemnaberis». Nihil tam facile, quam uilem plebiculam et indoctam contionem linguae uolubilitate decipere, quae quidquid non intelligit plus miratur.

('Cuando hables en la iglesia, no es el griterío del pueblo lo que se ha de suscitar, sino la compunción. Las lágrimas de los oyentes sean tus alabanzas. La palabra del presbítero esté inspirada por la lectura de las Escrituras. No te quiero ni declamador, ni deslenguado, ni charlatán, sino conocedor del misterio e instruido en los designios de tu Dios. Hablar con Engolamiento o precipitadamente para suscitar admiración ante el vulgo ignorante es propio

14 «De honroso, en dos maneras considero me ha sido honrosa esta poesía: si entendida para los doctos, causarme ha autoridad, siendo lanze forzoso venerar que nuestra lengua a costa de mi trabajo aya llegado a la perfeción y alteza de la latina, a quien no he quitado los artículos, como le parece a vuesa merced y essos señores, sino escusádolos donde no eran necessarios [...] Demás, que honrra me ha causado hazerme obscuro a los ignorantes, que essa es la distinción de los hombres doctos, hablar de manera que a ellos les paresca griego, pues no se han de dar las perlas preciosas a animales de cerda»» (Respuesta de don Luis de Góngora, p. 165).

${ }^{15}$ San Gregorio Nacianceno, padre de la iglesia griega, enseñó a san Jerónimo cuando éste estuvo en Constantinopla en torno al 379. San Jerónimo dirige esta epístola a Nepociano, presbítero que le pedía instrucción y consejos para ser un buen sacerdote. 
de hombres incultos. El hombre de frente altanera se lanza con frecuencia a interpretar lo que ignora, y si logra convencer a los demás, se arroga para sí mismo el saber. Mi antiguo maestro Gregorio Nacianceno, una vez que yo le pedí que me explicara qué significa en Lucas el sábado $\Omega m \diamond \diamond m \square \square * \square \square \bullet \square \square$, o sea, segundo-primero, se burló de mí con elegancia: «Sobre eso te instruiré en la iglesia; allí, cuando todo el pueblo aplaude, estás obligado a saber aun lo que ignoras, y si te callas, serás tildado de ignorancia por todos». Nada más fácil que engañar a un vulgo vil e indocto con la ligereza en el hablar, pues cuanto menos entiende, más admira') (San Jerónimo, Ad Nepotianum, 52, 8)

Juan de Jáuregui, detractor del nuevo estilo culto, citó el lugar de san Jerónimo en dos de sus textos: el Antídoto (1614-1615) y, más tarde, en el Discurso poético $(1624)^{16}$ :

El discurso de navegaciones que hace aquel viejo es generalmente horrendo y bronquísimamente relatado, tanto que hará dar de cabeza por las paredes a cualquier hombre de juicio. No hablo de aquellos que cuanto menos entienden lo que leen tanto más lo estiman y pasan adelante con su lectura muy sin pesadumbre. Otros se dan a creer que los versos difíciles de entender, ésos, cuestan mayor dificultad y estudio al escribir. ¡Notable erronia! No advierten que la pureza y hermosura de la elocución y su claridad, ésa, es la que se conpra con vivas gotas de sangre (Juan de Jáuregui, Antídoto, pp. 61-62)

Ya veo que la ciega plebe se alarga hoy a llamar cultos los versos más broncos y menos entendidos: tanto puede con su lengua la rudeza. Bien interpretan la palabra cultura. ¿Cuál será, me digan, más culto terreno, el de un jardín bien dispuesto donde se distribuyen con arte las flores y las plantas y dejan abierto camino por donde todo se registre y se goce, o un boscaje rústico, marañado, donde no se distinguen los árboles, ni dejan entrada ni paso a sus asperezas? No hay cosa tan fácil -decía Nacianceno [In epist. Hiero. Ad Nepotianum]- como engañar al vulgo y a los oyentes idiotas con la vana revolución de la lengua, porque esta gente, de aquello que menos entiende, hace mayor ostentación. Nihil tam facile quam vilem plebeculam et indoctam contionem linguae volubilitate decipere, quae quidquid non intelligit plus miratur (Juan de Jáuregui, Discurso poético, pp. 118-19).

También Quevedo citará parte de este lugar de san Jerónimo para contestar el argumento de que la poesía culta se destina al disfrute de una minoría docta. El pasaje

\footnotetext{
${ }^{16}$ Smith (1987: 50) y Schwartz (1987: 54, n. 14) señalaron su presencia en el Discurso poético.
} 
de Quevedo pertenece a la dedicatoria a Olivares, fechada en 1629, y que constituye el grueso de los preliminares literarios a su edición de la poesía de fray Luis de León, publicada en $1631^{17}$ :

$Y$ si los que afectan esta noche en sus obras, quieren alabanza por decir tiene dificultad el escribir nudos ciegos y no ser inteligibles, san Jerónimo ad Nepotianum los desnuda desta presunción cuando dice: Nihil tam facile, quam vilem plebeculam, et indoctam contionem linguae volubilitate decipere, quae quidquid non intelligit plus miratur (No hay cosa tan fácil como engañar la indocta plática y la vil plebe con la tarabilla de la lengua; porque la gente baja y ignorante más admira lo que menos entiende) (Quevedo, Preliminares literarios a las poesías de fray Luis de León, pp. 129-30)

Con frecuencia estas autoridades postulaban afirmaciones de valor general o amplio. Ello hace que un mismo pasaje pueda aplicarse a varios contextos y finalidades concretos. Así, el anterior lugar de san Jerónimo sobre la ignorancia del vulgo fue utilizado por Francisco Terrones del Caño en su Instrucción de predicadores (1617). En este caso, Terrones seleccionó dos fragmentos adecuados para apoyar su censura de los auditorios que sólo se detenían en lo aparente del sermón sin reparar en la esencia de su doctrina:

$Y$ así el sermón o oración, como él dice, si todo va deleitando, cansa presto, y si tiene medianamente el deleitar y principalmente el aprovechar, es oído mucho tiempo. Y cuán verificado he visto yo esto. Que en algunos predicadores, que entraban en la Corte con sus cascabeles, predicando dulzuras y donaires, y llevándose con esto hasta cuaresma y media todo el mundo tras sí; que luego son dejados por enfadosos, perseverando otros predicadores substanciales diez y veinte años, sin salir de allí, tan llenas las iglesias como el primero día, porque predican principalmente al provecho, y tienen lo que basta para deleitar. De manera que de los oyentes que no buscan el provecho no hay que cuidar mucho, porque son como vasos de yedra, que, si les echáis vino y agua, se sale el vino por los poros de la yedra, y se queda el agua sola: así se quedan con solas las flores y juguetes del sermón, y se olvidan luego de la substancia, y así no hay que hacer caso del seguir y aplauso de estos auditorios. San

${ }^{17}$ Rivers (1998: 22-26), Smith (1987: 47-52) y Schwartz (1987: 50-55) estudian las autoridades citadas en esta dedicatoria. También Cuevas (2003) ha analizado la intención de Quevedo en el ámbito de los modelos poéticos del Siglo de Oro, y estudia diversos aspectos de este escrito quevediano. 
Hierónimo, escribiendo a Nepotiano De vita clericorum, en el primero tomo dice: Docente te in ecelessia non clamor populi, sed gemitus suscitetur, lacrymae auditorum laudes tuae sint ... Nihil tam facile quam vilem plebeculam et indoctam concionem linguae volubilitate decipere, quae quidquid non intelligit, miratur (Francisco Terrones del Caño, Instrucción de predicadores, pp. 74-75).

\section{HORACIO: «PARTURIENT MONTES, NASCETUR RIDICULUS MUS»}

Otra cita de autoridades muy frecuente en estas discusiones literarias es el verso 139 del Arte Poética de Horacio («Parturient montes, nascetur ridiculus mus»), que aparece cuando Horacio habla de la sencillez que debe presidir la presentación del asunto y los objetivos del escritor ${ }^{18}$. El verso será reiterado para aludir a diversos usos ampulosos del estilo, en especial en los exordios. Señalaré algunos ejemplos.

Ya Quintiliano lo incluyó en su Institutio Oratoria $(8,3,20)$ cuando se ocupaba del ornato en las palabras. Al defender que era correcto usar voces sencillas y bajas si respetaban el decoro y la propiedad, el rétor incluye diversos ejemplos, entre ellos el citado verso del Arte poética horaciana:

Quaedam non tam ratione quam sensu iudicatur, ut illud «caesa iungebant foedera porca» fecit elegans fictio nominis, quod si fuisset «porco» uile erat. In quibusdam ratio manifesta est. Risimus, et merito, nuper poetam qui dixerat: «praetextam in cista mures rosere camilli». At Vergili miramur illud «Saepe exiguus mus»; nam epitheton «exiguus» aptum <et> proprium effecit ne plus expectaremus, et casus singularis magis decuit, et clausula ipsa unius syllabae non usitata addidit gratiam. Imitatus est itaque utrumque Horatius «Nascetur ridiculus mus.» Nec augenda semper oratio, sed summittenda nonnumquam est. Vim rebus aliquando uerborum ipsa humilitas adfert. An cum dicit in Pisonem Cicero: «Cum tibi tota cognatio serraco aduehatur», incidisse uidetur in sordidum nomen, non eo contemptum hominis quem

${ }^{18}$ Este es el pasaje del Arte poética: «Nec sic incipias, ut scriptor cyclicus olim:/ "Fortunam Priami cantabo et nobile bellum"/Quid dignum tanto feret hic promissor hiatu?/Parturient montes, nascetur ridiculus mus» ('Tampoco deberás comenzar como hacía en otro tiempo el escritor de ciclos épicos: «Voy a cantar el destino de Príamo y la ilustre guerra...». ¿Qué cosa digna de tan sublime y enfático comienzo dirá el que promete esto? Las montañas están de parto...: nacerá un ridículo ratón'). Los autores del Siglo de Oro adoptaron con frecuencia la variante parturiunt, que recogen algunos codices deteriores y san Jerónimo. 
destructum uolebat auxisse? (Quintiliano, Institutio Oratoria, 8, 3, 19-21).

('Hay cosas que no pueden juzgarse tanto por la razón como por el sentimiento, como el conocido verso «sellaron la alianza con la sangre de una jabalina sacrificada» [Virgilio, Eneida, 8, 641], al cual proporcionó elegancia la ficción del nombre, pues si hubiese sido «puerco», habría sido una voz vil. En otros casos la razón es manifiesta. Nos hemos reído con razón del poeta que dijo «los ratones cachorritos en la cesta / la toga púrpura del niño royeron». Por el contrario, admiramos aquel lugar de Virgilio «con frecuencia un diminuto ratón» [Geórgicas, 1, 181]; porque el epíteto «exiguus» ('diminuto') produjo una significación propia y adecuada, para que no esperásemos más, y el caso singular resultó más apropiado, y el raro monosílabo del final del verso añadió gracia. Así imitó Horacio ambos procedimientos: «nacerá un ridículo ratón» [Arte Poética 139]. Y no se debe elevar siempre el tono del discurso, sino que en ocasiones hay que bajarlo. Esta humildad de las palabras a veces da fuerza a las ideas. Pues cuando Cicerón dice en su discurso contra Pisón la frase «mientras toda tu parentela era traída en carreta», ¿parece que haya caído en una voz sórdida, o no más bien que por esta palabra hizo aumentar el desprecio hacia el hombre al que quería destruir?')

Ya san Jerónimo había citado el mismo verso del Arte poética al comienzo de su tratado Adversus Jovinianum, precisamente cuando censuraba los vicios que hacían ininteligible el estilo de Joviniano ${ }^{19}$. En 1589, Juan de Guzmán lo incluyó en su Primera parte de la Rhetorica cuando censuraba la excesiva hinchazón de los exordios:

${ }^{19}$ Éste es el pasaje que precede a la cita del Arte Poética en el tratado de san Jerónimo: «Pauci admodum dies sunt, quod sancti ex urbe Roma fratres cujusdam mihi Joviniani Commentariolos transmiserunt, rogantes, ut eorum ineptiis responderem, et Epicurum Christianorum, evangelico atque apostolico vigore conterream. Quos cum legissem, et omnino non intelligerem, coepi revolvere crebrius, et non verba modo atque sententias, sed singulas pene syllabas discutere, voleus prius scire quid diceret, et sic vel probare, vel redarguere, quod dixisset. Verum scriptorum tanta barbaries est, et tantis vitiis spurcissimus sermo confusus, ut nec quid loquatur, nec quibus argumentis velit probare quod loquitur, potuerim intelligere. Totus enim tumet, totus jacet: attollit se per singula, et quasi debilitatus coluber, in ipso conatu frangitur. Non est contentus nostro, id est, humano more loqui, altius quiddam aggreditur».Véase Migne PL XXIII, 221. Joviniano encabezó la herejía de los jovinianistas, y fue un adversario del ascetismo al que san Jerónimo refuta. Esta obra de San Jerónimo será una autoridad utilizada en varias ocasiones por preceptistas que censuraban el estilo de complejo ornamento. La usó González de Salas en los comentarios que acompañan su edición del Satiricon de Petronio, concretamente al capítulo 90; Salas cita el siguiente fragmento de Adversus Jovinianum (que precede inmediatamente al verso de Horacio): «Non est contentus nostro, id est, HVMANO more loqui: ALTIVS QUIDDAM adgreditur», y comenta a esta cita patrística: «Rectè, nam verbis vtuntur plerumque Poëtae ampullatis, tumentibusque, vt stilus elatè procedat, non humi repat, vt sermo hominum est familiaris, et quotidianus» (Commenta in T. Petroni Arbitri Satiricon, pp. 201-2). 
Desta suerte sin algunos exordios bien hinchados y fanfarrones, y todo el restante cuerpo del sermón es frágil y débil; por lo qual sería yo de parecer que los que en el sermón tuviessen poco que dezir, que también moderassen su exordio y lo conformassen con él, porque no se pueda dezir por ellos: Parturiunt montes, nascetur ridiculus mus (Juan de Guzmán, Primera parte de la Rhetorica, p. 171)

En 1617, Terrones del Caño lo vuelve a mencionar cuando previene sobre los peligros de prometer grandes cosas en la introducción del sermón:

La tercera, que no prometa el predicador en la introducción muchas y grandes cosas para tratar en el sermón, porque después suele no satisfacerse a lo prometido, y caerá en falta.

Nec sic incipias, ut scriptor cyclicus olim:

«Fortunam Priami cantabo et nobile bellum»

Quid dignum tanto feret hic promissor hiatu?

Parturiunt montes, nascetur ridiculus mus (Terrones del Caño, Instrucción de predicadores, pp. 109-10)

En 1629, Quevedo citó ese mismo pasaje de Quintiliano que contenía el verso de Horacio. Lo hace en el marco de los preliminares a su edición de fray Luis. Quintiliano y Horacio son aquí autoridades que esgrime Quevedo en defensa de la propiedad (proprietas) y claridad (perspicuitas) del estilo, virtudes que halla en la poesía de fray Luis y de las que, según él, carecen los versos de Góngora y sus seguidores:

De todo esto se asegura quien ama la propiedad y la luz, y la escribe y las razona. Severo censor es Quintiliano, y en el lib. 8 de sus Instituciones, cap. 3, alaba en Virgilio lo que un mal culto usurpador deste buen renombre arrojara por bajo y asqueroso. Virgilio en la Geórgica, lib. 4: Saepe exiguus mus (Muchas veces el pequeño ratón). Pondera el severo Fabio: Nam epitheton exiguus, aptum proprium efficit, ne plus expectaremus; et casus singularis magis decuit, et clausula ipsa unius syllabae non usitata addit gratiam; imitatus est utrumque Horatius: Nascetur ridiculus mus (Porque el epíteto pequeño, acomodado y propio, previene para que no esperemos más, y el caso singular fue más conveniente, y la cláusula de una sílaba añadió gracia. Las dos cosas imitó Horacio: Nacerá el ridículo ratón) (Quevedo, Preliminares literarios a las poesías de fray Luis de León, p. 149). 
En los anteriores ejemplos ya han podido apreciarse algunas citas de autoridades empleadas con fines diversos ${ }^{20}$. A continuación me centraré en este aspecto, para mostrar cómo esos saberes antiguos y consagrados se convertían a menudo en recursos argumentativos que los autores orientaban a sus intereses; de esta forma, un mismo pasaje podrá ser citado para defender ideas opuestas ${ }^{21}$.

\section{ARISTÓTELES Y LAS UERBA PEREGRINA}

Uno de esos casos es un pasaje donde Aristóteles (Retórica 3, 2, 1404b) habla de la claridad del lenguaje. Cuando Aristóteles se ocupa de aquellas voces y expresiones que se apartan de los usos comunes, reconoce que logran solemnidad en el estilo y que por ello conviene que en cierta medida se usen, aunque más en la poesía que en la prosa sencilla $^{22}$ :

pues el variar lo ordinario hace que la dicción sea más digna; porque lo mismo que les ocurre a los hombres con los extraños y los ciudadanos, les ocurre también con el estilo. Por eso es necesario hacer algo extraña la lengua, ya que se admira de los que están lejos, y lo que causa admiración es agradable. En la poesía esto lo producen muchos medios y conviene muy bien en ella, porque se sale más de lo ordinario en asuntos y personas de que habla, mas en la prosa sencilla conviene mucho menos, porque el asunto es inferior (Aristóteles, Retórica, 3, 2, 1404b).

${ }^{20}$ Es un aspecto muy conocido en los tratados de retórica, en especial al tratar los loci communes, que no son ideas usadas muchas veces en los discursos, sino ideas que por su carácter general e infinito pueden ser válidas para ilustrar muchos asuntos, incluso en tratamientos opuestos o enfrentados. Desde el enfoque de la nueva retórica también se reconoce este aspecto; véase Perelman y OlbrechtsTyteca (1994: $\S \S 70$ y 72).

${ }^{21}$ Sobre este aspecto véase Smith (1987: 50-51). En este trabajo espigaré ejemplos de varias obras, de entre los muchos que podrían aducirse al respecto. Como ejemplo ilustrativo pueden señalarse los Discursos apologéticos de Pedro Díaz de Rivas, compuestos como refutación de escritos anteriores que atacaban a Góngora: su examen muestra muchos lugares que habían sido citados antes como censura del poeta cordobés, y que Díaz de Rivas aducía ahora en su favor.

${ }^{22}$ De hecho, poco después vuelve a insistir en la moderación que, en general, es principio rector del estilo en las obras del Estagirita: «de entre éstos [nombres] los inusitados, los compuestos y los neologismos hay que usarlos pocas veces y en pocos lugares (dónde, lo diremos después; por qué, ya se ha dicho: desvían de lo adecuado a lo demasiado elevado» (Aristóteles, Retórica, 3, 2, 1404b). 
Fernando de Herrera abordó el uso de uerba peregrina en varios lugares de sus Anotaciones a Garcilaso ${ }^{23}$. En su breve comentario a la voz argén (Epístola a Boscán, v. 76) introduce el mencionado pasaje de Aristóteles como autoridad que apoya el uso de voces peregrinas en poesía:

Lícito es a los escritores de una lengua valerse de las vozes de otra; concédeseles usar las forasteras i admitir las que no se an escrito antes, i las nuevas, i las nuevamente fingidas, i las figuras del dezir, passándolas de una lengua en otra. I quiere Aristóteles que se admitan en la poesía vozes extrangeras, i que se mescle de lenguas para dar gracia a lo compuesto i hazello más agradable i más apartado del hablar común. Porque, como él dize en el libro tercero de la Retórica, las diciones estrañas hazen que la oración paresca más grande, como se ve en los peregrinos i extrangeros, que los ombres los admiten i se les afecionan más que a los suyos; $i$ assí, es de parecer que se haga peregrina la oración, porque los ombres admiran las cosas estrañas i agenas; i todo aquello que engendra admiración es suave. Pero esto se entiende en la poesía (Fernando de Herrera, Anotaciones a la poesía de Garcilaso, pp. 670-71)

Pedro Díaz de Rivas citó también ese mismo fragmento de Aristóteles para avalar el uso de voces peregrinas y nuevas en los poetas, y defender con ello a Góngora $^{24}$ :

Pero sería ynmensa obra el referir especialmente los modos con que este Poeta, para causar graçia y alteça, se aparta del estilo vulgar, viendo que todo lo inusitado es admirable. De lo cual ingeniosamente Aristótiles, li. 3 Rhetor., c. 2, hablando de los Poetas: Nam inusitata graviorem reddunt orationem, quod enim ad Peregrinos, atque advenas patimur, et etiam ipsum ad dictionem sustinemus Quo circa inusitatiora sunt adhibenda, haec enim ex omnibus admiramur, mirabile autem omne iucundum est. Reduce, pues, este gran Filósofo lo inusitado

${ }^{23}$ La consideración más extensa la desarrolló como anotación a la voz desbañe (Égloga 2, v. 772): defendía allí el uso de voces nuevas y peregrinas, sobre todo en poesía. Manejaba Herrera diversos argumentos: el haberlas introducido ya los autores latinos y algunos ilustres predecesores hispanos como Garcilaso; el ornamento y grandeza que proporcionan al estilo... Véanse Cuevas (1997), Morros (1998: 192-93) y Pepe y Reyes (2001: 849-53, n. 197 a 204), para las fuentes y otros detalles sobre la anotación de Herrera.

${ }^{24}$ Más adelante (Discursos apologéticos, pp. 50-51) Pedro Díaz de Rivas reconoce la oscuridad que las voces peregrinas y los tropos causan al estilo, y vuelve a mencionar, entre otros, este lugar de la Retórica de Aristóteles. Díaz de Rivas considera este rasgo propio de un estilo sublime que en las Soledades resulta adecuado al asunto que él defiende en el poema: «la peregrinaçión de un Príncipe, persona grande, su ausencia y afectos dolientes en el destierro, todo lo qual es materia grabe y debe tratarse afectuosamente con el estilo grabe y magnífico» (Discursos apologéticos, pp. 51-52) 
de el estylo al fin del Poeta, que es el deleite. Por lo qual no sólo inventaron los Poetas vozes, sino las propias alargaron, acortaron y mudaron en la locuçión las reglas ordinarias (Pedro Díaz de Rivas, Discursos apologéticos, p. 43).

Pero como en ese lugar de la Retórica Aristóteles recomendaba moderación en el uso de voces nuevas y extranjeras, también los detractores de Góngora y su estilo culto usarán su autoridad, en este caso para censurar lo que consideraban exceso en el poeta cordobés:

Aunque es verdad que al poeta heroico es lícito usar voces nuevas y extranjeras, según el arte de Aristóteles, el de Horacio y otros, juntamente es precepto suyo que en esto haya gran tiento y moderación (Juan de Jáuregui, Antídoto, p. 36)

\section{ESTACIO Y LICOFRÓN}

Una cita de autoridades bastante empleada por defensores y detractores del estilo culto pertenece a una de las Silvas de Estacio $(5,3)$. En este poema funerario dedicado a su padre (Epicedion in patrem), Estacio enumera los textos y autores explicados por su padre en su escuela de Nápoles (vv. 148-58). El verso 157 se refiere al griego Licofrón, poeta de minorías cultas y oscuro lenguaje, que mezclaba la lengua ática con voces de diversos dialectos, modificaba los nombres de personajes y lugares y, en general, sustituía la designación recta de las cosas por términos literarios complejos y rebuscados.

En sus Discursos apologéticos, Pedro Díaz de Rivas utilizó este verso de Estacio cuando incluyó a Licofrón en una serie de «Poetas excelentes, bien que obscuros» que aducía en defensa del estilo culto ${ }^{25}$ :

Esta doctrina puede confirmar el aplauso y veneración que hizieron los doctos de Poetas excelentes, bien que obscuros. Sírvanos por exenplo Persio, el qual, siendo obscuríssimo y como autor de enigmas, es muy estimado por su erudición, por la cultura y elegancia de sus versos, por lo poco plebeyo del estylo [...]. Entre los Griegos fueron celebrados muchos,

\footnotetext{
${ }^{25}$ Lo indicó ya Smith (1987: 50).
} 
bien que muy obscuros, por lo raro de su ingenio y doctrina, como el philósopho y poeta Heráclito [...]. Y el insigne escritor de tragedias, Lycophronte, tuvo epítheto de obscuro por las muchas tinieblas que derramó en sus obras. Estacio, 5 Sylva, 3, 32:

Latebrasque Lycophrontis atri.

$Y$ assí los grandes ingenios no fueron excluidos de el número de los Poetas, ni dexaron de alcançar el grado merecido a la excelencia de sus obras si la obscuridad de su estylo fue aconpañada de otras virtudes excelentes o provino de la alteça del dezir. Pues nuestros sagrados escriptores, espeçialmente los Prophetas, fueron casi ininteligibles, no sólo por los misterios altos que significan, sino por lo remoto y estraño de la oraçión y por las frasis poéticas; que, aunque escribieron en prosa, lo encunbrado de su espíritu los levantó a usar estylo semejante al de los Poetas (Pedro Díaz de Rivas, Discursos apologéticos, pp. 57-58).

Ese verso de Estacio también fue citado por Quevedo en sus preliminares a las poesías de fray Luis; pero en este caso, la referencia a la oscuridad (Lycophronis atri) dio pie a la censura quevediana ${ }^{26}$ :

$Y$ Estacio, en el libro $V$ de las Silvas (Epicedion in patrem), hablando de los poetas, cuando trata de Licofrón, que fue quien en griego enseñó esta seta, dice:

Carmina Battiade latebrasque Lycophronis atri;

(... escondrijos del enegrecido Licofrón).

No se pudieron estudiar palabras de mayor oprobio. Latebras atri (Escondrijos del denegrido Licofrón); y Licofrón aún tuvo disculpa, pues escribió un vaticinio que llama Alexandra. Que la palabra ater es condenada en el estilo de los poetas, consta de Horacio en la Arte poética:

Vir bonus et prudens versus reprehendit inertes,

Culpabit duros incomptis allinet atrum.

Transuerso calamo signum ambitiosa recidet

Ornamenta, parum claris lucem dare coget.

(Quevedo, Preliminares literarios a las poesías de fray Luis de León, pp. 140-41)

${ }^{26}$ El verso de Estacio y la obra de Licofrón no eran desconocidos para Quevedo, que había subrayado en su ejemplar de las Silvas de Estacio este verso referido a Licofrón, tal y como indicaron Hilarie y Craig Kallendorf $(2000: 148,165)$. Conocía también su poema Alexandra, del que poseía una traducción latina (se recoge en la bibliografía). En sus anotaciones a la Retórica de Aristóteles, Quevedo usó esta obra de Licofrón como ejemplo de frialdad en el estilo por el uso de compuestos, voces de varias lenguas y metáforas oscuras: al comentar un pasaje de la Retórica de Aristóteles (3, 3, 1406a34-35) sobre la frialdad del estilo, Quevedo anotó un caso de enigma atribuido a Licofrón: «Licofrón confundió y mezcló la oración en enigma, llamando a Xerxes pelorio, por decir igual a los montes [de Pelorum, "monte al este de Sicilia'], y "cirossines" [de los ladrones Skiro y Sinnis], por decir: "vir vastus"» (López Grigera, 1998: 163). Sobre estos aspectos, véanse Maldonado (1975) y López Grigera (1998: 161, n. 125 y 163). 
0, como lo muestra el que también hubiese sido citado por Francisco Fernández de Córdoba al final de su Parecer sobre las Soledades (p. 144):

Yo he dicho lo que e sentido sinceramente a la ley de christiano, y amigo como lo e protestado y profesado en quanto alcança mi juicio. Vm. con el suyo, pues es tan bueno, lo pondere y vea lo que se debe hazer y consúltelo (si le pareciere) con hombres de letras y echará de ver que le aconsejo como hombre de bien y servidor suyo. Según Horacio en el arte:

Vir bonus, et prudens versus reprehendent inerteis;

culpabit duros, incomptis allinet atrum

transverso calamo signum, ambitiosa recidet

ornamenta, parum claris lucem dare coget,

arguet ambigue dictum, mutanda notabit

fiet Aristarchus, nec dicet cur ergo amicum

offendam in nugis? Hae nugae seria ducent

in mala derisum semel exceptumque sinistrae.

(Francisco Fernández de Córdoba, Parecer sobre las Soledades, p. 144).

\section{LA POÉTICA DE ARISTÓTELES Y LA VIRTUD DE LA ELOCUCIÓN}

Para adaptar las autoridades a la opinión propia, a menudo se fragmenta el pasaje que se cita, y se selecciona la parte más adecuada a los intereses de cada escrito. Es un procedimiento habitual en la inserción de citas, y muestra su fuerte carácter $\operatorname{argumentativo~}^{27}$. La retórica lo contemplaba en varios lugares; por ejemplo, cuando al hablar de los exempla y la auctoritas se indicaba que podían narrarse o citarse enteros o sólo en los pasajes que resultasen de interés.

Un destacado ejemplo de fragmentación de una cita lo constituye el lugar de la Poética (1458a-1459b) de Aristóteles donde se abordaba la virtud de la elocución. Para Aristóteles, esa virtud se cifraba en el justo medio, en un estilo equilibrado: «La excelencia de la elocución consiste en que sea clara sin ser baja», dice el Estagirita. Al

${ }^{27}$ Quintiliano lo advertía ya para el exemplum: «Intuendum igitur est, totum simile sit an ex parte, ut aut omnia ex eo sumamus aut quae utilia sunt» (Institutio Oratoria, 5, 11, 6). Es aspecto estudiado por la crítica; por ejemplo Smith (1987: 51) y Compagnon (1979: 17-39), que al estudiar la esencia de la cita también indica que su génesis está en extraer un fragmento de un texto más amplio y transplantarlo a otro contexto; véase también Martínez Fernández (2001: 81-91). 
intentar precisar ese equilibrio, Aristóteles rechaza en primer lugar las voces demasiado vulgares. A continuación pasa a mencionar diversos recursos que logran el extremo contrario, esto es, una elocución excelente: uerba peregrina, alteración de voces, metáforas... Aristóteles reconoce la grandeza que todos ellos aportan al estilo, pero luego matiza que debe moderarse su uso para no caer en un estilo confuso por excesivamente ornamentado ${ }^{28}$. Este es el pasaje en cuestión:

La excelencia de la elocución consiste en que sea clara sin ser baja. Ahora bien, la que consta de vocablos usuales es muy clara, pero baja; por ejemplo, la poesía de Cleofonte y la de Estenelo. Es noble, en cambio, y alejada de lo vulgar la que usa voces peregrinas; y entiendo por voz peregrina la palabra extraña, la metáfora, el alargamiento y todo lo que se aparta de lo usual. Pero si uno lo compone todo de este modo, habrá enigma o barbarismo; si a base de metáforas, enigma; si de palabras extrañas, barbarismo. Pues la esencia del enigma consiste en unir, diciendo cosas reales, términos inconciliables Ahora bien, según la composición de los vocablos no es posible hacer esto, pero sí lo es por la metáfora; por ejemplo, «vi a un hombre que había soldado con fuego bronce sobre un hombre», y otros semejantes. Por consiguiente, hay que hacer, por decirlo así, una mezcla de estas cosas; pues la palabra extraña, la metáfora, el adorno y las demás especies mencionadas evitarán la vulgaridad y bajeza, y el vocablo usual producirá la claridad (Aristóteles, Poética, 1458a18-33).

Esta posición intermedia de Aristóteles (común a Horacio, Quintiliano y otros muchos preceptistas) dio pie a que detractores y defensores del estilo culto fragmentasen las citas de este lugar de la Poética en razón de sus intereses: los defensores del estilo culto citaron aquellos pasajes donde Aristóteles alababa las virtudes ornamentales de estos recursos, y sus censores aquellos donde reprobaba las negativas consecuencias de su excesiva frecuencia y oscuridad.

Pedro Díaz de Rivas defendió en sus Discursos apologéticos el estilo de las Soledades de Góngora. Su defensa se organiza como una refutación de las distintas objeciones que se hicieron al poeta cordobés. Una de ellas le acusaba de usar voces extranjeras. Díaz de Rivas reunió autoridades que mostraban lo conveniente de su presencia. Dentro de ellas, extrae del anterior pasaje de la Poética de Aristóteles

${ }^{28}$ Pues como norma general considera que «la mesura es necesaria en todas las partes de la elocución» (Aristóteles, Poética, 1458b12-13). 
aquella parte donde se reconoce que las voces de diversas lenguas engrandecen la expresión y omite, lógicamente, cualquier matiz referente a los peligros de su uso:

Enpero los Poetas griegos y latinos, con mayor atrevimiento, usurparon vozes peregrinas, para mover y deleitar y para conseguir un estilo según los preceptos de la Poesía. De lo qual Aristótiles, in Poetica: illa veneranda Poesis, et omne prorsus plebeium excludens, quae peregrinis utetur vocabulis, peregrinum voco varietatem linguarum, etc. (Pedro Díaz de Rivas, Discursos apologéticos, p. 41).

Lo mismo hace Francisco Fernández de de Córdoba en su Examen del Antídoto (h. 1615), cuando examina las causas que Aristóteles da para la grandeza del estilo a fin de comprobar que se cumplen en el poema de Góngora:

De los vulgares Toscanos a Monseñor de la Casa hazen muchos cabeça y exemplar de los que an escrito con estilo magnífico, pero sin duda no es él solo, pues de Torquato Tasso, del caro, del Chiabrera, del Guarini y del Marino vemos canciones y sonetos, que espiran magnificencia. Señal es que la sufre el Poema, y que la puede tener el de las Soledades. Veamos si la tiene. La magnificencia de la elocuçión de tres cosas nace principalmente de ordinario en la Poesía, según Aristóteles, de variedad de lenguas; de translaciones; de extensiones: «Illa veneranda (dice él de la virtud de la dictión) et omne prorsus plebeium excludens, que peregrinis utetur vocabulis. Peregrinum voco varietatem linguarum, translationem, extensionem, tum quodcunque a proprio alienum est» (Francisco Fernández de Córdoba, Examen del Antídoto, p. 428).

Pero en su Parecer sobre las Soledades (1614), el mismo Francisco Fernández de Córdoba se centraba más en analizar las objeciones que le sugería el poema de Góngora que en defenderlo de los ataques de sus censores. Por ello, al citar el mismo lugar de la Poética omitió el fragmento que sí incluía en el Examen del Antídoto para alabar la grandeza de su estilo, y citó sólo aquellas partes donde más se censuraba la oscuridad que produce el abuso de estos recursos:

Juzgo mi Señor que lo que a la hermosura destas Soledades, y vago lienço de Flandes, offusca, y haze sombra (efecto suyo proprio), es la obscuridad, quanto más affectada, y puesta en práctica, tanto más viciosa, pero seguida de Vm. a quien yo no quiero persuadir con autoridad mía (que no me atribuyo tanta), sino con la de los más graves Autores del mundo, que procuran desterrarla de los escritos bien formados. 
Aristóteles maestro mayor desta obra en su Poética hablando de la virtud de la Dictión. Dictionis autem virtus, vt perspicua sit non tamen humilis (Francisco Fernández de Córdoba, Parecer sobre las Soledades, p. 133).

Así sucede en la Poesía y en cualquiera elocución; no an de ser áridas, ni desnudas, no ni por imaginación; pero ni tan llenas de adorno que con él se desadornen, ahoguen y confundan [...] oygamos a Aristóteles en el $3^{\circ}$ de la Rethorica: Praeterea incongrua sit oratio, cum nos reddideris nisi coniunxeris vtrique congruentiam; vt, sonum aut colorem videre quidem commune non est sentire vero. Obscura autem etiam cum dicis non apponendo, sed multa interserendo hoc pacto. Constitui enim cum tecum haec atque haec; et sic collocutus essem, proficisci, y el mismo en la Poética: Peregrinum voco varietatem linguarum traslationem, extensionem, tum quodusque a proprio alienum est. Verum si quis haec omnia simul congerat, vel enigma efficiet vel Barberismum, enigma quidem, si translationes, barberismum vero, si linguas (Francisco Fernández de Córdoba, Parecer sobre las Soledades, p. 135).

Juan de Jáuregui también citó este pasaje de la Poética de Aristóteles al censurar la oscuridad en el capítulo VI de su Discurso poético $(1624)^{29}$. Al comienzo de ese capítulo Jáuregui rechaza la dicotomía que asociaba la oscuridad del poema al destinatario erudito, y su claridad al bajo e ignorante. Para ello matiza la diferencia entre claridad y perspicuidad, y argumenta que la perspicuitas, virtud contraria a la oscuridad del lenguaje, implica también el rechazo de lo vulgar. En ese contexto integró como autoridad su propia traducción del comienzo de ese pasaje de la Poética de Aristóteles, donde se insistía en la conveniencia de la claridad $^{30}$ :

Sea el primer supuesto, que no es ni debe llamarse oscuridad en los versos el no dejarse entender de todos, y que a la poesía ilustre no pertenece tanto la claridad como la perspicuidad. Que se manifieste el sentido, no tan inmediato y palpable, sino con ciertos resplandores no penetrables a la vulgar vista: a esto llamo perspicuo y a lo otro claro. Cierto es que los ingenios plebeyos y los no capaces de alguna elegancia no pueden extender su juicio a la majestad poética, ni ella podría ser clara a la vulgaridad menos que despojada de las gallardías de su estilo, del brío y alteza de sus figuras y tropos, de sus conceptos grandes y

${ }^{29}$ La posición de Jáuregui sobre este vicio de la dicción queda bien definida en un pasaje donde (Jáuregui, Discurso poético, pp. 133-34), aun admitiendo distintas capacidades para entender los textos, critica a los cultos que no sean comprendidos ni aun por los más eruditos. Estudian las ideas literarias de Jáuregui Matas Caballero (1990) y Rico García (2002).

${ }^{30}$ Smith (1987: 50) comentó lo siguiente sobre la traducción de Jáuregui: «His translation of the 'texto del escándalo' is polemically shaded». 
palabras más nobles: circunstancias y adorno forzosos en la oración magnífica. Por quien dijo Aristóteles [de Poet., cap. 22]: La virtud de la oración poética consiste en que sea manifiesta, pero no humilde. Humilde será si se abate a la inteligencia de todos (Jáuregui, Discurso poético, pp. 125-26)

En los preliminares a las poesías de fray Luis (1629) Quevedo centró sus razones en ese mismo pasaje de la Poética ${ }^{31}$. Quevedo critica a quienes - como Díaz de Rivas o Fernández de Córdoba - utilizaron su parte inicial para alabar la grandeza del estilo culto, y les opone el resto del lugar aristotélico. Ofrece, pues, un clásico uso argumentativo de las autoridades basado en citar la parte que el rival omitía intencionadamente:

Dispuesto este discurso con tal autoridad, propondré el texto del escándalo, que en la Poética

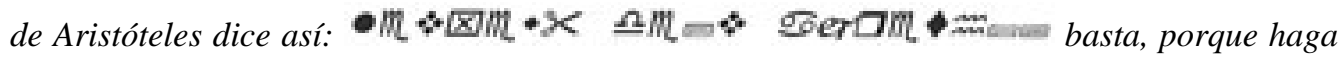
más fe, empezar el texto de que es tal la versión: Dictionis autem virtus, et perspicua sit, non tamen humilis, quae igitur ex propriis nominibus constabit, maxime perspicua erit humilis tamen, exemplum sit Cleophontis Stheneli, quae poesis illa veneranda, et omne plebeium excludens, quae peregrinis utetur vocabulis: peregrinum voco varietatem linguarum, translationem, extensionem, tum quodcunque a proprio alienum est (La virtud de la dicción ha de ser perspicua, no humilde: la que constare de nombres propios será perspicua; sea ejemplo de la humilde la poesía de Cleofonte y de Sténelo. Aquélla es venerable y excluye todo lo que es plebeyo, que usa de vocablos peregrinos; peregrino llamo la variedad de lenguas, translación, extensión, y todo lo que es ajeno de lo propio). Este lugar del Filósofo, a los que descansaron en este punto la lección - temiendo por larga jornada la de su desengaño, estando en otro renglón inmediato- ha dado ocasión de errar, no modo de escribir. Son hombres que despiden el estudio en llegando a la cláusula que desean. Aclaman estos renglones por texto expreso, en disculpa de los barbarismos y solecismos que escriben, de que resulta la enigma. Pocos pasos que dieran los ojos en el libro, leyeran el desengaño en estas palabras consecutivas: Verum si quis haec omnia simul congerat, vel aenigma efficiet, vel barbarismum. Aenigma quidem si translationes, barbarismum quidem si linguas (Empero si alguno rebuja todas estas cosas juntas, o hará enigma u barbarismo: enigma si amontona translaciones; barbarismo, si lenguas) (Quevedo, Preliminares literarios a las poesías de fray Luis de León, pp. 130-34).

${ }^{31}$ Quevedo utilizó el mismo lugar en su Comento contra setenta y tres estancias que don Juan Ruiz de Alarcón ha escrito...: «Aristóteles en su Poética, hablando de la locución dice: "La bondad de la locución es que sea clara y no humilde!”» (p. 398b). 
Por supuesto, ello no impide que el propio Quevedo fragmente a su conveniencia esta y otras citas de autoridades en este mismo escrito ${ }^{32}$. Como muestra de que Quevedo tampoco estaba libre de pecado, inmediatamente recurre a otro procedimiento argumentativo para orientar el texto de Aristóteles a favor de sus juicios literarios. No se trata ahora citar un fragmento conveniente a la postura propia, sino de torcer el sentido de la fuente en beneficio de la opinión que se defiende:

Pocos pasos que dieran los ojos en el libro, leyeran el desengaño en estas palabras consecutivas: Verum si quis haec omnia simul congerat, vel aenigma efficiet, vel barbarismum. Aenigma quidem si translationes, barbarismum quidem si linguas (Empero si alguno rebuja todas estas cosas juntas, o hará enigma u barbarismo: enigma si amontona translaciones; barbarismo, si lenguas). Aquel vel que la versión puso, Aristóteles en el texto lo usurpa por et,

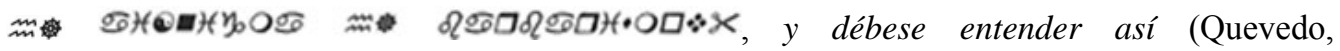
Preliminares literarios a las poesías de fray Luis de León, p. 134).

Para acercar el texto de Aristóteles a su postura, Quevedo se apoyó en uno de sus comentaristas italianos, Vincenzo Maggi, cuya edición de la Poética siguió ${ }^{33}$. Aristóteles empleó una correlación disyuntiva (ne en latín se tradujo como vel ... vel en la versión de Maggi seguida por Quevedo. Su valor disyuntivo ('o bien ... o bien ...') se recoge en la traducción de Quevedo cuando dice «o hará enigma u barbarismo» (p. 134). Pero Quevedo incorpora y acepta el comentario donde Vincenzo Maggi considera — con un razonamiento un tanto tendencioso- que esa correlación disyuntiva la usó Aristóteles con el valor de et ... et ('no sólo ... sino también ...', 'tanto ... como ...'), cuyo significado es más fuerte pues el segundo miembro incluye y se añade al primero; según esta interpretación de Maggi (que hace suya Quevedo), habría de entenderse que quien amontona voces peregrinas cometerá a un tiempo enigma y

${ }^{32}$ Ya Smith (1987:. 51), Martinengo 2000: 216) y Cuevas (2003: 197) señalaron que Quevedo manipula este pasaje aristotélico y su traducción para adecuarlo a su argumentación.

${ }^{33}$ Tal y como señaló Rivers (1998: 38, n. 15 y p. 41, n. 18). Quevedo manejó la traducción latina de la Poética elaborada por Pazzi, a través de la edición y comento de Maggi. Basándose en el texto de Pazzi, Vincenzo Maggi publicó en 1550 sus Vincentii Madii Brixiani et Bartholomaei Lombardi Veronensis in Aristotelis Librvm de Poetica commvnes explanationes, que dividen el texto en 157 secciones (particula) acompañadas de una explanatio de Maggi y Lombardi, y una annotatio de Maggi. Sobre estas cuestiones, véanse Weinberg (1961: 371-88) y García Yebra (1974: 18-22, 34-49). Comenté este pasaje de Quevedo en Azaustre (2003: 71-72). 
barbarismo; se refuerza así la censura a los cultos, que usaban a menudo esas voces. Esta es la anotación de Maggi al pasaje de Aristoteles ${ }^{34}$ :

Sciendum est, Aristotelem vocem, VEL pro ET accepisse, cum ait: VERVM SI QVIS HAEC OMNIA SIMVL CONGERAT, VEL AENIGMA EFFICIET, VEL BARBARISMVM. si enim oratio ex metaphoris complicetur, aenigma facit: si item accesserit linguae, barbarismum cum aenigmate faciet. VEL autem pro ET, usurpari supra demonstratum est (Maggi, Annotationes, particula CXVI, p. 117)

\section{QUINTILIANO Y PETRONIO: EL EQUILIBRIO DE ESTILO Y LA FRAGMENTACIÓN DE LA CITA}

Volviendo a la cita fragmentada de una autoridad, otro caso lo constituye la siguiente cita de Quintiliano hecha por Quevedo en sus preliminares a la poesía de fray Luis. En el texto abajo señalado, Quevedo extrae dos fragmentos de un pasaje más extenso donde Quintiliano (Institutio Oratoria, 8, 2, 1-3) hablaba de la claridad del lenguaje, y afirmaba que debía huirse de las voces obscenas y bajas, pero que ello no debía llevar al extremo opuesto de evitar todas las palabras usuales y comunes aun siendo necesarias. Quintiliano ilustra esta última parte de su afirmación con dos ejemplos de un orador que llamó «hierbas ibéricas» a la retama o hiniesta, y «peces endurecidos con la salmuera» a la salazón (salsamenta); en ambos casos, sus expresiones resultaron ridículas en su pretendida elevación. Este es el pasaje completo de Quintiliano:

Perspicuitas in uerbis praecipuam habet proprietatem, sed proprietas ipsa non simpliciter accipitur. Primus enim intellectus est sua cuiusque rei apellatio, qua non semper utemur. Nam et obscena uitabimus et sordida et humilia. Sunt autem humilia infra dignitatem rerum aut ordinis. In quo uitio cauendo non mediocriter errare quidam solent, qui omnia quae sunt in usu, etiam si causae necessitas postulet, reformidant; ut ille qui in actione Hibericas herbas ne solo nequiquam intellegente dicebat, nisi inridens hanc uanitatem Cassius Seuerus spartum dicere eum uelle indicasset. Nec uideo quare clarus orator duratos muria pisces nitidus esse credideret quam ipsum id quod uitabat (Quintiliano, Institutio Oratoria, 8, 2, 1-3)

\footnotetext{
${ }^{34}$ El pasaje se tradujo aut...aut en la versión de Riccoboni seguida por García Yebra (1974: 209).
} 
('La claridad en las palabras aspira sobre todo a la propiedad, pero la propiedad tiene más de un sentido. En efecto, en primer lugar se entiende por ella la denominación de cada cosa por su nombre. Pero esta palabra propia no siempre la emplearemos, porque evitaremos, por ejemplo, los términos obscenos, sucios y bajos. Por bajo entiendo los que están por debajo de la dignidad del asunto o del rango del orador. Para evitar este vicio algunos cometen a menudo el error bastante grave de temer emplear palabras corrientes, incluso si la necesidad del asunto las exige. Como aquel que en un proceso hablaba de «hierbas ibéricas», expresión que él sólo entendía, sin utilidad para la causa, a no ser que Casio Severo, para burlarse de esa vana afectación, no hubiese indicado que quería hablar de la retama. $Y$ no ve por qué ese abogado distinguido pudo creer que la perífrasis «peces conservados en salmuera» era más elegante que la palabra que deseaba evitar [salsamenta: 'salazón']')

Mezclando interesadamente las dos vertientes de este pasaje, Quevedo atacó el uso de una voz muy querida de los cultos (y también del Quevedo burlesco), la sinécdoque cuerno en lugar de la voz cabrito ${ }^{35}$ : según Quevedo, al utilizar un tropo que eludía la designación recta del objeto, los cultos resultaron malsonantes en el sustituto literario y sus alusiones, y cayeron en el inadecuado uso de expresiones bajas para un poema que se pretendía elevado:

\begin{abstract}
Hoy, señor, por no decir lo que sin asco ni escrúpulo es lícito, hay algunos que dicen lo que es torpe y abominable; Quintiliano lo enseña: Obscena vitabimus et sordida et humilia. $Y$ en el propio lib. 8, cap. 2, acusa a éstos que ni saben dejar ni escoger: Nec video quare clarus orator duratos muria pisces, nitidius esse crediderit, quam ipsum id quod vitabat (Ni veo por qué el claro orador creyó era mejor decir «los peces con la muria», que lo mismo que quería decir). Sea ejemplo si en España alguno, por excusar la voz cabrito — que es decente, y no es sucia ni vil ni deshonesta- dijese cuerno, que es todo esto junto con ignominia, y de mala composición de letras (Quevedo, Preliminares literarios a las poesías de fray Luis de León, pp. 156-57)
\end{abstract}

${ }^{35}$ Cuerno es voz bastante usada en los poemas mayores de Góngora, con diversos significados; ver Callejo y Pajares (1985). Se censura aquí por ser sinécdoque ('parte por el todo') que, pretendiendo ser voz elevada y nueva frente a cabrito, se convierte en vulgar y de alusiones burlescas en relación con el matrimonio. En relación con los vv. 329-34 de la Soledad primera, donde un cabrito se niega a asistir a las bodas pues el matrimonio no recibe de buen grado sus cuernos, comentó Jáuregui en su Antídoto: «Y el gamo, que no quería yr delante de los desposados por causa de los cuernitos que tenía [...] es bien puerca y torpe malicia» (p. 120); más detalles ofrece Jammes (1994: 329-34, n. 334). Jáuregui también censuró (Antídoto, p. 113) la extensa perífrasis de la Soledad primera (vv. 153-60) para referirse al macho cabrío y, concretamente, su verso 156: «breve de barba y duro no de cuerno». El inadecuado uso de expresiones bajas en las Soledades fue asimismo censurado por Pedro de Valencia en su Carta a Góngora..., como ya he señalado. Véase también lo dicho por Martinengo (1967: 163-64; 2000: 218). 
Las citas de Quintiliano se taracearon de la siguiente forma: la frase inicial (Obscena vitabimus ... Institutio Oratoria 8, 2, 1) reproduce sólo la parte donde Quintiliano afirmaba que debían evitarse las voces bajas y obscenas, y luego se ilustra con el citado ejemplo del cabrito y el cuerno. La segunda frase de Quintiliano (Nec video... Institutio Oratoria 8, 2, 3) es el ejemplo que corresponde a la idea del rétor latino que completaba la anterior cita fragmentada: allí Quintiliano precisaba que huir de lo obsceno no debía llevar al extremo opuesto de sustituir una voz necesaria por una expresión más oscura en su pretendida elevación; justo lo que sucede con la perífrasis duratos muria peces ('peces endurecidos con la salmuera') en lugar de salsamenta ('pescado salado').

Otro caso de cita fragmentada vinculado a esta polémica literaria tiene como fuente un pasaje del Satiricon (118) de Petronio: por boca de Eumolpo se advierte sobre las dificultades y exigencias de la poesía, que a menudo atrae a los jóvenes con una engañosa apariencia de disciplina sencilla ${ }^{36}$. Tras esta advertencia, Petronio aconseja evitar las expresiones vulgares, citando para ello un conocido verso de Horacio $^{37}$. A continuación complementa esa exigencia, pues reclama proporción y equilibrio al pedir que las sentencias no sobrepasen el ámbito del discurso, sino que se ajusten a él para así lucir de forma más perfecta. Al final, Homero y Virgilio aparecen como ejemplos excelentes de poetas que siguieron la senda de la verdadera poesía ${ }^{38}$ :

${ }^{36}$ «Multos, inquit [Eumolpus], ô iuuenes, carmen decepit: nam vt quisque; versum pedibus instruxit, sensumque; teneriorem verborum ambitu intexuit, putavit se continuò in Heliconem venisse. Sic forensibus ministeriis exercitati, frequenter ad carminis tranquillitatem, tanquam ad portum faciliorem refugerunt, credentes facilius poëma exstrui posse, quam controuersiam sententiolis vibrantibus pictam. Ceterum neque; generosior spiritus vanitatem amat, neque concipere, aut edere partum mens potest nisi ingenti flumine litterarum inundata» (Petronio, Satiricon, 118, p. 59 / líneas 23-31).

37 «Odi profanum vulgus, et arceo»: es el verso inicial de una conocida oda de Horacio $(3,1)$, donde se critica el afán de riqueza imperante en Roma. El verso pertenece a un tópico exordio donde el poeta promete himnos nunca oídos, y se dirige a su destinatario (vírgenes y mancebos), del que excluye al vulgo. Esta cita de Horacio constituye otro ejemplo de adaptación de una autoridad a un contexto e intención diferente, al aplicar ese genérico rechazo del vulgo a su lenguaje.

38 «Praeterea curandum est, ne sententiae emineant extra corpus orationis expressae; sed intexto vestibus colore niteant. Homerus testis, \& Lyrici, Romanusque Virgilius, \& Horatii curiosa felicitas. Ceteri enim aut non viderunt viam, qua iretur ad carmen; aut visam timuerunt calcare» (Petronio, Satiricon, 118, p. 59/ línea 34 y p. 60/ líneas 1-3). Se utiliza para ello la conocida metáfora del cuepo humano aplicada al discurso. Los comentarios (Commenta, p. 315) de González de Salas a su edición del Satiricon (ver bibliografía) se hacen eco de ello, y señalan la deuda del pasaje de Petronio con el De Oratore de Cicerón. 
Effugiendum est ab omni verborum, vt ita dicam, vilitate; et sumendae voces a plebe submotae, $v t$ fiat «Odi profanum vulgus, et arceo». Praeterea curandum est, ne sententiae emineant extra corpus orationis expressae; sed in texto vestibus colore niteant. Homerus testis, et Lyrici, Romanusque Virgilius, et Horatii curiosa felicitas. Ceteri enim aut non viderunt viam, qua iretur ad carmen; aut visam timuerunt calcare (Petronio, Satiricon 118, pp. 59/ líneas 31-34, 60/ líneas 1-4).

('Hay que huir, por decirlo así, toda la vulgaridad de los vocablos, y tomar voces alejadas de la plebe, para que sea cierto aquello de «Odio al vulgo ignorante y lo tengo lejos». Además de esto debemos procurar que las sentencias no se eleven fuera del cuerpo del discurso, sino que su color brille dentro del texto. Testigos son Homero y los líricos y el romano Virgilio y la meticulosa felicidad de Horacio. Pues los demás, o no vieron la senda por la que se va a la poesía, o habiéndola visto temieron recorrerla')

En un pasaje de sus Discursos apologéticos, Pedro Díaz de Rivas defiende a Góngora de las acusaciones que censuraban su estilo por ser demasiado elevado, y le recomendaban una mayor sencillez que lo hiciese más comprensible. Díaz de Rivas responde con una máxima común a los defensores del estilo culto: que el poeta no debe someter su estilo al criterio del vulgo, sino más bien rechazarlo ${ }^{39}$. Como es preceptivo, esa defensa se acompañaba de diversas autoridades que avalaban la opinión de Díaz de Rivas: el Libro de la erudición poética de Luis Carrillo de Sotomayor, Pontano y su Accio, Juvenal... A continuación Díaz de Rivas incluye el anterior pasaje del Satiricon de Petronio. Su cita está deliberadamente fragmentada: omite precisamente aquella parte donde Petronio recomendaba que las sentencias no desbordasen el marco del discurso, pues no se adecuaba tanto a la intención laudatoria del copioso estilo de Góngora. Díaz de Rivas cita sólo la parte inicial que rechazaba el uso de expresiones bajas, y enlaza luego con los ejemplos excelentes de Homero y Virgilio:

39 «Dirá alguno yo confiesso que nuestro Poeta alcançó con este modo de deçir un estylo lebantado, pero pudiera moderarse, no baxándose a dezir vulgarmente y juntamente dándose a entender de todos; el qual modo de dezir tuvieron muchos Poetas griegos, latinos y toscanos. A esto respondo que el Poeta no tiene obligación de refgular la alteça de su ingenio con el juizio del vulgo, antes todos huyeron de agradarle» (Pedro Díaz de Rivas, Discursos apologéticos, p. 56). El propio Góngora lo manifestó en su Respuesta a una carta de censura a las Soledades (p. 165), pasaje citado arriba. 
A este sentimiento aludió Petronio, hablando de la Poesía: Effugiendum est ab omni verborum (ut ita dicam) vilitate, et sumendae voces a plebe summotae, ut fiat: Odi prophanum vulgus et arceo ... Homerus testis, et Lyrici Romanusque Virgilius, et Horatii curiosa felicitas. Ceteri enim aut non viderunt viam, qua iretur ad carmen, aut versum timuerunt calcare. Luego, si nuestro Poeta no tiene obligación de contentar a muchos, bien podrá sólo conponer para los doctos con estylo sumamente sublime, en el qual éstos travaxen con mucho gusto (Pedro Díaz de Rivas, Discursos apologéticos, p. 57)

En su Discurso poético, Juan de Jáuregui recurrirá a ese mismo lugar de Petronio, y citará también el fragmento inicial donde se recomienda rechazar las voces humildes. Sin embargo, su posterior comentario orienta el pasaje a criticar a los poetas cultos de su tiempo quienes, según Jáuregui, entendían mal ese precepto y abusaban de él, con el resultado de afectar en demasía el estilo con un exceso de voces foráneas ${ }^{40}$ :

Es cierto que el estilo debe huir las dicciones humildes y usar las más apartadas de la plebe, como entre otros muchos dijo Petronio: Effugiendum est ab omni verborum vilitate, et sumendae voces a plebe summotae. Saben esto nuestros poetas o hanlo oído decir, y llenos de furiosa afectación no sólo buscan voces remotas de la plebe, sino del todo ignoradas en nuestra lengua y traídas en abundancia de las ajenas (Juan de Jáuregui, Discurso poético, p. $71)$.

Al comienzo del capítulo III del Discurso poético, Jáuregui volverá a citar parte de ese lugar de Petronio. Dentro de su consideración de las rarezas de estilo como vicios peligrosos, Jáuregui no niega que usados con destreza puedan suponer aciertos en el poema. Pero la excesiva reiteración con que suelen utilizarlos los malos poetas convierte en yerros esos posibles aciertos, y sólo los escritores excelentes logran utilizar con fortuna tales rasgos de estilo. En ese contexto es donde menciona algunos ejemplos de poetas que lograron esa rara excelencia, y ahí cita la frase del pasaje de Petronio que se refiere a Virgilio:

\footnotetext{
${ }^{40}$ Jáuregui continúa su razonamiento entre las pp. 71-77. Recurre a otras autoridades para apoyar su recomendación de mesura en el uso de uerba peregrina, cuestión a la que me he referido antes. En su Discurso poético, Jáuregui citará otros pasajes del Satiricon (118), tal y como apuntaron Romanos (1978) en las notas a su edición, y Rico García (2002: XXVII) en el estudio preliminar a su edición del Antídoto.
} 
Con esta advertencia (a lo que yo juzgo), dice Petronio del poeta lírico: Et Horatii curiosa foelicitas, porque mediante la industria y artificio de Horacio tuvieron felicidad sus atrevimientos poéticos (Juan de Jáuregui, Discurso poético, p. 90)

A partir de esa frase de Petronio, Jáuregui se adentra en una digresión sobre el significado de la voz curiosus, cuyo sentido orienta claramente hacia su postura de prevenir los peligros de la dificultad de estilo. Es otro ejemplo de adecuación argumentativa de la cita, enriquecido a su vez por un nuevo acopio de autoridades:

Reparemos en la voz curiosus, que en el más notorio sentido de los latinos significa el demasiado diligente en inquirir novedades. Es vicio la curiosidad, vicio que excede todo límite en la diligencia y se distingue della tanto como la superstición de la religión [Quint. Lib. 8, cap. 3]: ut a diligenti curiosus et a religione superstitio distat. De suerte que Petronio, atribuyendo a Horacio la curiosa felicidad, muestra que fue feliz en lo vicioso que excedió venturosamente. Y más encarece el exceso diciendo curiosa foelicitas que si dijera foelix curiositas, porque según Nigidio (a quien Gelio llama doctísimo) [ in A. Gel. Lib. 4, cap. 9], este modo de fenecer las dicciones: vinosus, mulierosus, religiosus, nommosus, explica un exceso grande en aquello de que se habla, y en eso funda que aun la palabra religiosus se recibía en mala parte. Así curiosus tendrá el mismo vigor, reforzando el sentido vicioso de la curiosidad y gravando su exceso. Varrón en sus etimologías dice [De ling. Lat., lib. 5]: que es curioso el que sobremanera se arde en cuidado. Cura, quod cor urat; curiosus, qui hoc praeter modum uritur.

De aquí infiero que el poeta felizmente curioso, según origen latino, puede decir escapa de las llamas: no es menos su dicha (Juan de Jáuregui, Discurso poético, pp. 90-91)

Quevedo también usará ese lugar de Petronio en sus preliminares a la poesía de fray Luis de León. Cita el mismo pasaje donde se rechazaba el uso de voces bajas y vulgares; pero lo hace como primera parte parte de un razonamiento que luego censurará la excesiva ampulosidad en el lenguaje. Para ello, Quevedo completa esa cita del Satiricon con otra extraida de su comienzo (Satiricon, 2), donde se censura la vana palabrería de la oratoria asiánica, aquí identificada con el estilo culto ${ }^{41}$. Esta segunda

${ }^{41}$ Quevedo cita fragmentos del pasaje de Petronio, que ocupan las pp. 1-2, líneas 18-9 y 1-18 en la edición de González de Salas. Véanse también los comentarios de éste (pp. 7-14 de sus Commenta in T. Petroni Arbitri Satiricon). 
cita completa el razonamiento de Quevedo, que en conjunto defiende un ideal de estilo respetuoso con la máxima del decoro: el rango de la expresión debe adecuarse la materia («El arte es acomodar la locución al sujeto»), y habrán de evitarse los dos extremos de la dicción, el vulgar y el excesivamente hinchado ${ }^{42}$ :

El arte es acomodar la locución al sujeto. Todo lo dijo Petronio Árbitro mejor que todos. Oiga vuestra excelencia sin prolijidad la arte poética en dos renglones: Efugiendum est ab omni verborum (ut ita dicam) vilitate, et sumendae voces a plebe semotae, ut fiat. «Odi profanum vulgus, et arceo» (Hase de huir de toda la vileza de los vocablos, y hanse de escoger las voces apartadas de la plebe, porque se pueda decir: aborrecí el vulgo profano). Mas débese juntar esto con lo que dijo al principio de su libro (que más parece, según viene a propósito, fingido que citado); él dice con quienes habla: Pace vestra liceat dixisse primi omnem eloquentiam perdidistis, leuibus enim, atque inanibus sonnis ludibria quaedam excitando, fecistis ut corpus orationis eneruaretur, et caderet. Nondum umbraticus doctor ingenia deleuerat... grandis, et ut ita dicam, pudica oratio non est maculosa, nec turgida, sed naturali pulcritudine exurgit. Nuper ventosa istec et enormis loquacitas Athenas ex Asia commigrauit, animosque iuuenum ad magna surgentes, veluti pestilenti quodam sidere adflauit, ac ne carmen quidem sani coloris enituit (Séame lícito decir con vuestra licencia, que sois los primeros que echaron a perder toda la elocuencia, y componiendo cosas ridículas con vanos y leves sones, hicistes que el cuerpo de la oración desmayado cayese. Aún no había el dotor escuro y sombrío borrado los ingenios. La grande y decorosa oración no es mostruosa y hinchada, antes se endereza con natural hermosura. Poco ha que esta inorme y fanfarrona parlería de Asia vino a Atenas; y los ánimos de los mancebos que se alentaban a grandes impresas los hirió de contagio a manera de pestilencial constelación, y de verdad ni un verso se vio de buen color) (Quevedo, Preliminares literarios a las poesías de fray Luis de León, pp. 143-45).

\footnotetext{
${ }^{42}$ Schwartz (1987: 53-54) señaló la presencia de estos lugares de Petronio en el Discurso poético de Jáuregui. Martinengo (2000: 217; 1967: 161-62) analizó la interpretación quevediana de esta cita de Petronio.
} 
Se han señalado varios pasajes como ejemplos que podrían ampliarse no sólo en el marco de la discusión literaria sobre el estilo culto, sino como un comportamiento general en el uso de las autoridades. A través de esos textos se ha visto cómo la fragmentación y taracea de citas con fines argumentativos adapta una misma obra y pasaje a intenciones diversas, e incluso a la defensa de juicios literarios opuestos. Las autoridades mencionadas a propósito del estilo culto en poesía constituyen, pues, un bagaje de citas compartidas por los defensores y censores de ese estilo. En último término, son una muestra más de que la argumentación — como la retórica, de la que es parte- no atiende sólo a la verdad del asunto, sino también al triunfo de una determinada opinión.

\section{REFERENCIAS BIBLIOGRÁFICAS}

\section{a) Bibliografía primaria:}

ARISTÓTELES. Poética, Valentín García Yebra (ed.). Madrid: Gredos, 1974.

Aristóteles. Retórica, Antonio Tovar (ed.). Madrid: Instituto de Estudios Políticos, 1971.

Carrillo de Sotomayor, L. Libro de la erudición poética, Angelina Costa (ed.). Sevilla: Alfar, 1987.

Ciceron. De inventione, Guy Achard (ed.), Paris: Les Belles Lettres, 1994.

CiCERon. De Oratore, Edmond Courbaurd y Henri Bornecque (eds.). Paris: Les Belles Lettres, 1927-1938, 3 vols.

Cicerón. Tópica, Henri Bornecque (ed.). Paris: Les Belles Lettres, 1924.

DíAz DE Rivas, P. Discursos apologéticos por el estylo del Poliphemo y Soledades, obras poéticas del Homero de Hespaña D. Luis de Góngora y Argote, en Documentos gongorinos, Eunice Joiner Gates (ed.). México: El Colegio de México, 1960, pp. 31-67.

Estacio. Silves, Henri Frère y H. J. Izaac (eds.). Paris: Les Belles Lettres, 1961. 
Fernández de CóRdoba, F. Parecer de Don Francisco de Córdoba acerca de las Soledades a instancia de su Autor. En Orozco, E. En torno a las «Soledades» de Góngora, 130-45. Granada: Universidad de Granada, Granada, 1969.

FERnÁNDEZ DE CóRdobA, F. Examen del Antídoto o Apología por Las Soledades de Don Luis de Góngora contra el autor de El Antídoto. En ARTiGAs, M. Don Luis de Góngora y Argote. Biografía y estudio crítico, 400-67. Madrid: Real Academia Española, 1925.

GóngorA, L. de. Respuesta de don Luis de Góngora. En Carreira, A. «La controversia en torno a las Soledades. Un parecer desconocido, y edición crítica de las primeras cartas». En Hommage à Robert Jammes, 162-67. Toulouse: Presses Universitaires du Mirail, 1994.

GÓNGORA, L. de. Soledades, Robert Jammes (ed.). Madrid: Castalia, 1994.

GonzÁlez de Salas, J. Commenta in T. Petroni Arbitri Sariricon. Ver Petronio.

GRANADA, L. de. Los seis libros de la Retórica eclesiástica o de la manera de predicar, vertidos al español de orden del Ilmo. Obispo de Barcelona, Barcelona, 1770. Madrid: Rivadeneyra, 1879, 466-642 (B.A.E., nº 11).

GuzMÁn, J. de. Primera parte de la Rhetorica (Alcalá de Henares, 1589), Blanca Periñán (ed.), Pisa: Giardini, 1993, 2 vols.

Hermógenes. En Téón, Hermógenes, Aftonio. Ejercicios de retórica, $\mathrm{M}^{\mathrm{a}}$ Dolores Reche Martínez (trad.), Madrid: Gredos, 1991.

Herrera, F. de. Anotaciones a la poesía de Garcilaso, Inoria Pepe y José María Reyes (eds.). Madrid: Cátedra, 2001.

Horacio. Odes et épodes, François Villeneuve y Joseph Hellegouarc'h (eds.). Paris: Les Belles Lettres, 1991.

JÁuregui, J. de. Antídoto contra la pestilente poesía de las «Soledades», José Manuel Rico García (ed.). Sevilla: Universidad de Sevilla, 2002.

JÁuregui, J. de, Discurso poético. Advierte el desorden y engaño de algunos escritos, Melchora Romanos (ed.), Madrid: Editora Nacional, 1978.

JerónImo, san. Adversus Jovinianum. En Jacques P. Migne (PL). Patrologiae cursus completus. Omnium SS Patrum, Doctorum scriptorumque ecclesiasticorum. Series latina, XXIII, 221. Paris: 1859. Reimpresión en Turnhout: Brepols, 19561985,168 vols. 
JerónImo, san, Epistula ad Nepotianum. En Epistolario, Juan Bautista Valero (ed.). Madrid: Biblioteca de Autores Cristianos, 1993.

Licofrón. Alexandra, Poema obscurum, Josephi Scaligeri (ed.). Ludguni: Ludovicus Elzevirius, 1597 (BNM R/21758) (ejemplar que fue propiedad de Quevedo).

MagGi, V. Vincentii Madii Brixiani et Bartholomaei Lombardi Veronensis in Aristotelis Librvm de Poetica commvnes explanationes: Madii vero in evndem librvm propriae annotationes. Eiusdem de Ridiculis: Et in Horatii librum de arte Poetica interpretatio. In fronte praeterea operis apposita est Lombardi in Aristotelis Poeticam praefatio, Venetiis: in officina Erasmiana Vincentii Valgrisii, MDL (Manejo la reproducción facsimilar editada en München: Wilhelm Fink Verlag, 1969).

Petronio. Le satiricon, Alfred Ernout (ed.). Paris: Les Belles Lettres, 1931.

Petronio, Satiricon, T. Petroni Arbitri E.R. Satiricon, José Antonio González de Salas (ed.). Francofurti: cura Wolfgangi Hofmanni, MDCXXIX (Biblioteca de la Universidad de Santiago de Compostela, sign. 14455).

Quevedo, F. de. Comento contra setenta y tres estancias que don Juan Ruiz de Alarcón ha escrito... En Obras completas. Prosa, Felicidad Buendía (ed.), 398-407. Madrid: Aguilar, 1986.

Quevedo, F. de. La culta latiniparla, Antonio Azaustre Galiana (ed.). En Obras completas en prosa, Alfonso Rey (dir.), vol. 1, tomo 1, 79-117. Madrid: Castalia, 2003.

Quevedo, F. de. Preliminares literarios a las poesías de fray Luis de León, Antonio Azaustre Galiana (ed.). En Obras completas en prosa, Alfonso Rey (dir.), vol1, tomo 1, 119-61. Madrid: Castalia, 2003.

Quintiliano. Institutio Oratoria, Jean Cousin (ed.). Paris, Les Belles Lettres, 19751980, 7 vols. Rhetorica ad Herennium, Guy Achard (ed.). Paris: Les Belles Lettres, 1989.

Terrones del CAÑo, F. Instrucción de predicadores, Félix G. Olmedo S. I. (ed.). Madrid: Espasa-Calpe, 1960. 


\section{b) Bibliografía secundaria:}

ANDRIEU, J. (1949). «Procédés de citation et de raccord». Revue des Études Latines, 26, 268-93.

Azaustre Galiana, A. (1996). «Citas y ejemplos en la argumentación de Virtud militante, de Francisco de Quevedo». En Scripta Philologica in Memoriam Manuel Taboada Cid, I, 289-98. A Coruña: Ediciones da Universidade da Coruña.

Azaustre GalianA, A. (2003). «Cuestiones de poética y retórica en los preliminares de Quevedo a las poesías de fray Luis de León». La Perinola. Revista de Investigación Quevediana, 7, 61-102.

Compagnon, A. La seconde main ou le travail de la citation. Paris: Éditions du Seuil.

Cuevas, C. (1997). «Teoría del lenguaje poético en las Anotaciones de Herrera». En Las «Anotaciones» de Fernando de Herrera. Doce estudios, Begoña López Bueno (ed.), 157-72. Sevilla: Universidad de Sevilla.

Cuevas, C. (2003). «La poética imposible de Quevedo. (Don Francisco, editor de fray Luis)». La Perinola. Revista de Investigación Quevediana, 7, 191-208.

García Yebra, V. (ed.) (1974). Aristóteles. Poética. Madrid: Gredos.

HENDRICK, G. L. (1906). «Literary sources in Cicero's Brutus and the technique of citation in dialogue». American Journal of Philology, 27, 184-99.

JAMMES, Robert (ed.) (1994). Góngora. Soledades. Madrid: Castalia.

Kallendorf, H. y C. (2000). «Conversations with the dead: Quevedo and Statius, annotation and imitation». Journal of the Warburg and Courtlaud Institutes, 63, 131-68.

LAusberg, H. (1966). Manual de retórica literaria. Fundamentos de una ciencia de la literatura, José Pérez Riesco (trad.). Madrid: Gredos.

LóPez GrigerA, L. (1998). Anotaciones de Quevedo a la Retórica de Aristóteles. Salamanca: Gráficas Cervantes.

MALDONADO, F. C.R. (1975). «Algunos datos sobre la composición y dispersión de la biblioteca de Quevedo». En Homenaje a la memoria de Don Antonio RodríguezMoñino, 405-28. Madrid: Castalia, Madrid. 
Martinengo, A. (1967). Quevedo e il simbolo alchimistico. Tre studi. Padova: Liviana Editrice.

Martinengo, A. (2000). «La descripción del caballo (Job, 39, 19-25) y la noción de evidentia en la poética quevediana». La Perinola. Revista de Investigación Quevediana, 4, 215-28.

MARTínez FERNÁNDEZ, J. E. (2001). La intertextualidad literaria (Base teórica y práctica textual). Madrid: Cátedra.

Matas Caballero, J. (1990). Juan de Jáuregui. Poesía y poética. Sevilla: Diputación Provincial.

Morros Mestres, B. (1998). Las polémicas literarias en la España del Siglo XVI: a propósito de Fernando de Herrera y Garcilaso de la Vega. Barcelona: Quaderns Crema.

PePE, I. y J. Ma . REYES (2001). Anotaciones a la poesía de Garcilaso. Madrid: Cátedra.

Perelman, Ch. y L. Olbrechts-Tyteca (1994). Tratado de la argumentación. La nueva retórica, Julia Sevilla Muñoz (trad.). Madrid: Gredos.

PletT, H. F. (1993). «Intertextualidades». Criterios, 64-94.

Rico GARCíA, J. M. (2001). La perfecta idea de la altísima poesía. Las ideas estéticas de Juan de Jáuregui. Sevilla: Diputación de Sevilla.

Rico GarcíA, José Manuel (ed.) (2002). Jáuregui, J. de. Antídoto contra la pestilente poesía de las «Soledades». Sevilla: Universidad de Sevilla.

RIVERS, E. L. (1998). Quevedo y su poética dedicada a Olivares. Estudio y edición. Pamplona: Eunsa (Anejos de La Perinola, no 3).

Romanos, M. (1983). «Lectura varia de Góngora. Opositores y defensores comentan la Soledad Primera». En Serta Philologica F. Lázaro Carreter II. Estudios de literatura y crítica textual, 435-47. Madrid: Cátedra.

Romanos, M. (ed.) (1978). Jáuregui, J. de. Discurso poético. Advierte el desorden y engaño de algunos escritos. Madrid: Editora Nacional, Madrid.

Roses Lozano, J. (1994). Una poética de la oscuridad. La recepción crítica de las «Soledades» en el siglo XVII. Madrid-London: Támesis.

SCHLICHER, J. J. (1905). «The moods of indirect quotation». American Journal of Philology, 26, 60-88. 
SCHWARTZ, L. (1987). Quevedo: discurso y representación. Pamplona: Eunsa.

Smith, P. J. (1987). Quevedo on Parnassus. Allusive Context and Literary Theory in the Love-Lyric. London: The Modern Humanities Research Association.

Weinberg, B. (1961). A History of Literary Criticism in the Italian Renaissance. Chicago: University of Chicago Press, 2 vols. 